\title{
Genetic diversity and structure of the globally invasive tree, Paraserianthes lophantha subspecies lophantha, suggest an introduction history characterised by varying propagule pressure
}

\author{
G. D. Thompson ${ }^{1,4}$ - D. M. Richardson ${ }^{1}$ - J. R. U. Wilson ${ }^{1,2}$ • D. U. Bellstedt ${ }^{3}$ • \\ J. J. Le Roux ${ }^{1}$
}

Received: 1 June 2015 / Revised: 17 February 2016 / Accepted: 3 March 2016

(C) Springer-Verlag Berlin Heidelberg 2016

\begin{abstract}
An emerging insight in invasion biology is that intra-specific genetic variation, human usage, and introduction histories interact to shape genetic diversity and its distribution in populations of invasive species. We explore these aspects for the tree species Paraserianthes lophantha subsp. lophantha, a close relative of Australian wattles (genus Acacia). This species is native to Western Australia and is invasive in a number of regions globally. Using microsatellite genotype and DNA sequencing data, we show that native Western Australian populations of $P$. lophantha subsp. lophantha are geographically structured and are more diverse than introduced populations in Australia (New South Wales, South Australia, and Victoria), the Hawaiian Islands, Portugal, and South Africa. Introduced populations varied greatly in the amount of genetic diversity contained within them, from being low (e.g. Portugal) to high (e.g. Maui, Hawaiian Islands).
\end{abstract}

Communicated by M. Wirthensohn

Electronic supplementary material The online version of this article (doi:10.1007/s11295-016-0984-0) contains supplementary material, which is available to authorized users.

\section{J. J. Le Roux}

jleroux@sun.ac.za; jacoleroux01@gmail.com

1 Centre for Invasion Biology, Department of Botany and Zoology, Stellenbosch University, Private Bag X1, Matieland 7602, South Africa

2 South African National Biodiversity Institute, Kirstenbosch Research Centre, Claremont 7735, South Africa

3 Department of Biochemistry, Stellenbosch University, Matieland 7602, South Africa

4 Present address: Biotechnology Platform, Agricultural Research Council, Private Bag X05, Onderstepoort 0110, South Africa
Irrespective of provenance (native or introduced), all populations appeared to be highly inbred $\left(F_{I S}\right.$ ranging from 0.55 to 0.8 ), probably due to selfing. Although introduced populations generally had lower genetic diversity than native populations, Bayesian clustering of microsatellites and phylogenetic diversity indicated that introduced populations comprise a diverse array of genotypes, most of which were also identified in Western Australia. The dissimilarity in the distribution and number of genotypes in introduced regions suggests that nonnative populations originated from different native sources and that introduction events differed in propagule pressure.

Keywords Biological invasions · Multiple introductions · Population genetics $\cdot$ Propagule pressure $\cdot$ Tree invasions

\section{Introduction}

Large-scale human-mediated movements of species outside of their native ranges have in many instances led to the establishment of invasive populations. The introduction dynamics (i.e. origin, route, number, and size of introductions) of newly introduced species can profoundly impact their genetic makeup on their new range (Taylor and Keller 2007), with implications for invasiveness (Lee 2002). Crucially, the interplay between the genetic composition of introduced populations and their introduction history is influenced by intra-specific diversity and genetic structure within the native range (e.g. see Le Roux et al. 2011). In some instances, genetic structure in the native range may translate into locally adapted differences and, depending on introduction dynamics (e.g. multiple vs. single introductions), this may have important implications for performance, risk assessment, and management of 
introduced species (Scott et al. 1998; Wardill et al. 2005; Thompson et al. 2011).

Multiple introductions can allow populations to overcome the constraints associated with genetic bottlenecks and density dependence, often experienced by non-native species (Barrett and Husband 1990; Blackburn et al. 2011). For example, the introduction of individuals from several previously disjunct and genetically divergent native populations can lead to new genetic recombinations, increased genetic diversity, and higher adaptive potential in the introduced range (Sakai et al. 2001; Lee 2002). This, coupled with strong novel selection pressures in the new range, can contribute to rapid evolution and increased invasiveness (Lavergne and Molofsky 2007). Recombination events can increase if introduced populations have been present in the new range for a long time, if multiple introductions occurred continuously, or if non-native species are selectively bred for human use such as forestry (Richardson et al. 2015).

Woody plant species used in forestry and agriculture have been widely distributed and cultivated for centuries, in many instances resulting in invasive populations (Thuiller et al. 2006; Rejmánek and Richardson 2013). Such species tend to have complex introduction histories (Le Roux et al. 2011) and are often introduced repeatedly to a range of different ecosystems and from varied native provenances over extended periods (e.g. Acacia mearnsii; Poynton 2009). These species also possess a number of traits associated with invasiveness, including rapid growth under a range of environmental conditions. For example, Australian wattles from the genus Acacia are a large group of species $(>1000)$ that have been widely disseminated for economic gain. Wattles are considered a model group in invasion biology because of the number and the extent of invasions that resulted following these intentional introductions (Richardson et al. 2011, 2015).

Paraserianthes lophantha (Willd.) I.C. Nielsen is within the sister genus to Australian wattles (Brown et al. 2011; Miller et al. 2011). This woody tree species has similar ecological attributes (e.g. preference for Mediterranean-type climates) and invasive distributions to a number of Australian wattles and is subject to similar management strategies (Impson et al. 2011). P. lophantha displays high levels of morphological variation (Brown et al. 2011), and two subspecies are currently recognised: subspecies lophantha in Western Australia and subspecies montana in Indonesia, New Guinea, and the Solomon Islands (Nielsen 1992). While no detailed introduction records of $P$. lophantha are available, there is evidence supporting the international export of mainly subspecies lophantha for ornamental and silvicultural purposes to a number of regions globally (Barneby and Grimes 1996, Henderson 2001, GBIF 2015).

P. lophantha subsp. lophantha is considered invasive in the Canary Islands and Chile (Randall 2002), New Zealand, Portugal, South Africa (Henderson 2001), and southern
California (Stirton 1978). P. lophantha is also invasive in Hawaii, but morphological evidence led Oppenheimer et al. (2002) to suggest that these populations belong to subspecies montana. Translocations within Australia have resulted in naturalised populations in New South Wales, South Australia, and Victoria (Nielsen 1992; Barneby and Grimes 1996; Walsh and Entwisle 1996). In South Africa, P. lophantha subsp. lophantha invades the margins of native forests and forestry plantations, riverbanks, and wooded ravines (Henderson 2001; Alston and Richardson 2006; Gaertner et al. 2012). It produces large seed banks that are viable for several years which make control of established infestations challenging (Wilson et al. 2011). It is considered an environmental transformer as it fundamentally alters the structure and function of invaded habitats. For example, $P$. lophantha is a nitrogen fixer with the ability to alter soil chemistry, a common phenomenon associated with woody legume invasions, including wattles (e.g. Yelenik et al. 2004).

We aim to improve our understanding of $P$. lophantha subsp. lophantha invasions by assessing global genetic diversity and population genetic structure using two types of molecular markers. Given the large native range size of P. lophantha subsp. lophantha in Australia, and because species that are not frequently traded are likely to have come from only a few introductions (Lockwood et al. 2005), we hypothesised that (1) globally introduced populations will harbour substantially less genetic diversity than populations in the native range; and (2) there will be population genetic structure in native Western Australian populations but not in introduced populations. In addressing these issues, we hope to shed light on the global movement of the species, with a particular emphasis on P. lophantha subsp. lophantha invasions in South Africa.

\section{Materials and methods}

\section{Sampling and DNA isolation}

P. lophantha subsp. lophantha was sampled from 11 localities across the native range in Western Australia; 11 sites elsewhere in Australia where the species has been introduced (two sites in New South Wales, four sites in South Australia, and five sites in Victoria); 13 sites in South Africa; and one site in Portugal (Table S1, Fig. S1, Fig. 1). We also sampled one population from Maui in the Hawaiian Islands, thought to represent $P$. lophantha subsp. montana (Oppenheimer et al. 2002). Leaf material from 238 individuals (between 4 and 20 individuals per site) was collected and stored on silica gel until DNA extraction. Whole genomic DNA was extracted using the cetyltrimethylammonium bromide (CTAB) method as described by Doyle and Doyle (1990). 
a) Level 1 Genetic clusters $K=2$
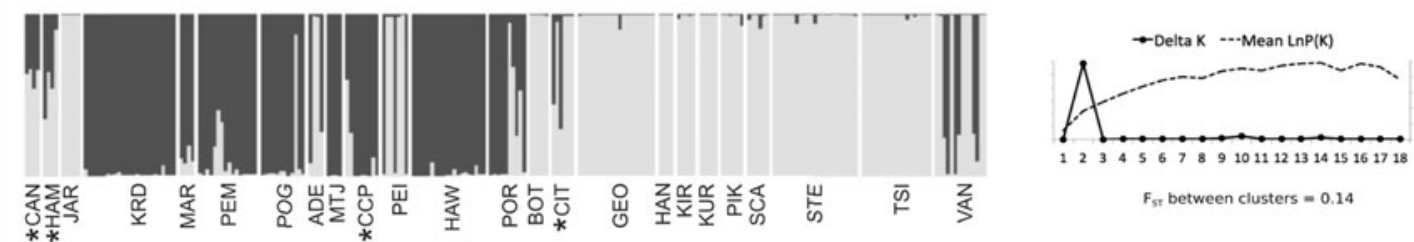

b) Level 2 Genetic clusters $K=6$
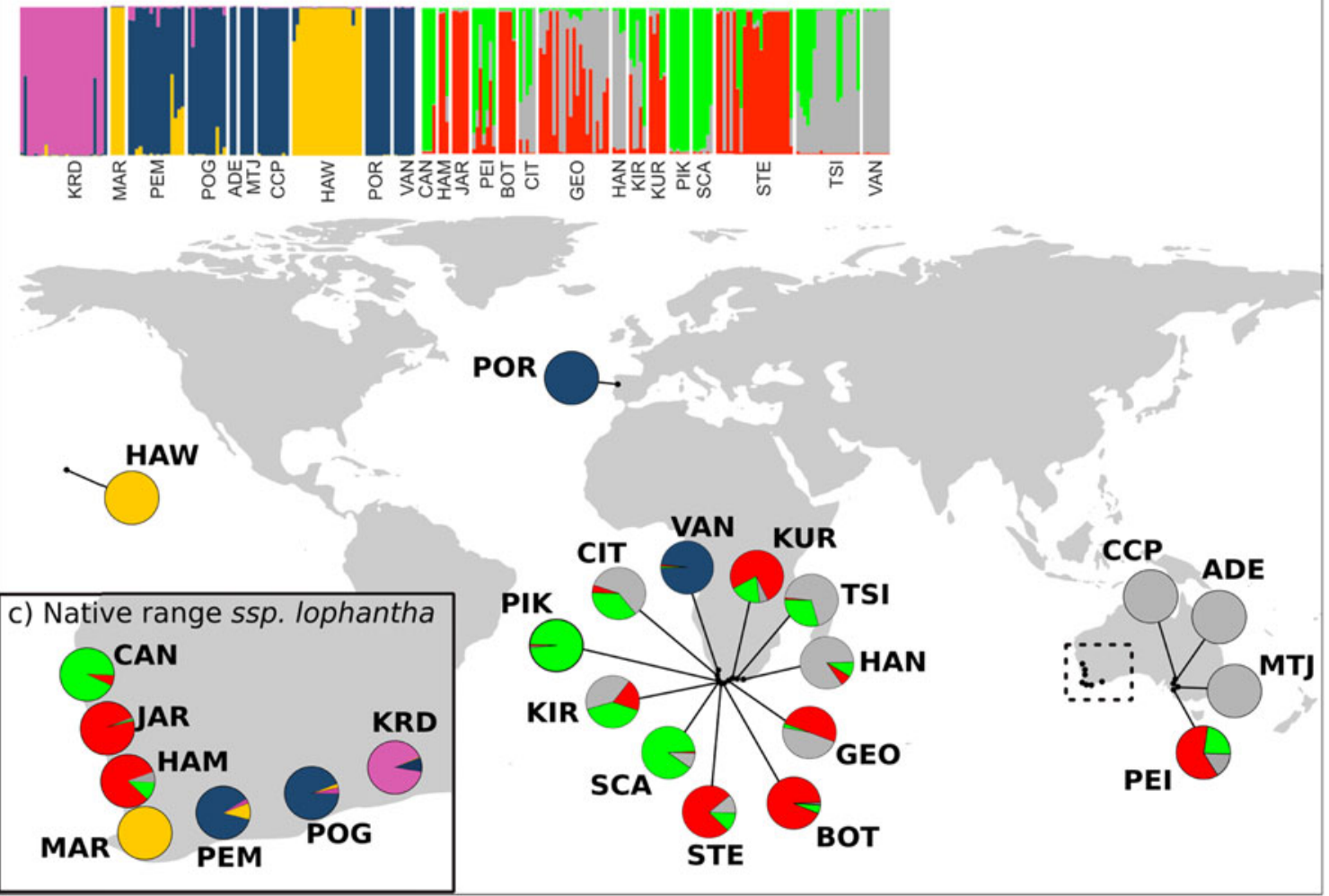

Fig. 1 Hierarchical clustering of native and introduced populations of Paraserianthes lophantha subspecies lophantha genotyped at 11 nuclear microsatellite loci. Populations were sampled from invasive ranges in Australia, the Hawaiian Islands, Portugal, and South Africa (b) and the native range in Western Australia (c). Each bar in the bar plots represents an individual. Level 1 of the STRUCTURE analysis identified the number of genetic clusters $(K)$ as 2 (a). Populations marked with

asterisks had an individual that was not assigned confidently to either of the two genetic clusters and were excluded from clustering in level 2 (b). The second level of the STRUCTURE analysis estimated six genetic clusters $(K=6)$ for all samples. Mapped pie charts represent the proportional makeup of six genetic clusters of individual populations. Locality codes are explained in Table S3

\section{Amplification of microsatellite markers}

Microsatellites are useful to detect contemporary changes in the genetic makeup of populations, like changes in allele frequencies due to genetic drift, and the occurrence of genetic bottlenecks (Sunnucks 2000). Six nuclear microsatellite loci previously developed for $P$. lophantha subspecies lophantha (Brown and Gardner 2011) and 43 microsatellites developed for Acacia mangium (Butcher et al. 2000), Acacia saligna (Millar and Byrne 2007), and an A. mangium $\times$ Acacia auriculiformis hybrid (Ng et al. 2005) were tested for amplification using conditions described for their development. Successfully cross-amplified loci were tested for polymorphism in 24 Western Australian

individuals and 24 individuals from the Hawaiian Islands. Eleven highly polymorphic microsatellites ( $>6$ alleles) were selected for further analyses. The forward primers of all loci were fluorescently end-labelled with 6-FAM, HEX, VIC, or NED. Four multiplex PCRs were done per individual, using the KAPA2G Fast Multiplex PCR kit (KapaBiosystems, Cape Town, South Africa). PCR conditions for multiplex PCRs are provided in Table S2. Each $25 \mu \mathrm{L}$ reaction contained $12.5 \mu \mathrm{L}$ of $2 \mathrm{X}$ KAPA2G Fast Multiplex Mix (KapaBiosystems, Cape Town, South Africa), $10 \mu \mathrm{M}$ each forward and reverse primer, $2 \mu \mathrm{L}$ of template DNA $(\sim 10 \mathrm{ng} / \mu \mathrm{L})$, made up to $25 \mu \mathrm{L}$ with $\mathrm{dH}_{2} \mathrm{O}$. Thermocycling consisted of initial denaturation at $95{ }^{\circ} \mathrm{C}$ for $3 \mathrm{~min}$, followed by 35 cycles of 
denaturation at $95{ }^{\circ} \mathrm{C}$ for $15 \mathrm{~s}$, multiplex-specific annealing (Table S2) for $30 \mathrm{~s}, 72{ }^{\circ} \mathrm{C}$ for $60 \mathrm{~s}$, and final extension at $72{ }^{\circ} \mathrm{C}$ for $30 \mathrm{~s}$. All PCR products were sized relative to a molecular size standard (LIZ500-250, PE Applied Biosystems). Fragment sizing was conducted using an ABI Prism 3100 Genetic Analyzer (Applied Biosystems, Foster City, USA) and visualised using GENEMARKER ${ }^{\circledR}$ version 1.95 (SoftGenetics LLC ${ }^{\circledR}$, PA, USA).

\section{Microsatellite utility, population genetic diversity}

Scored microsatellite loci were tested for departures from Hardy-Weinberg equilibrium for each population separately using GENEPOP v 4.1 and 10,000 steps in the Markov chain (Rousset 2008). For each population, the following genetic diversity indices were calculated in FSTAT v. 2.9.3.2 (Goudet 2001): number of polymorphic loci $\left(P_{L}\right)$, number of private alleles $\left(P_{A}\right)$, mean number of alleles $\left(N_{A}\right)$, mean observed and expected heterozygosities $\left(H_{O}\right.$ and $\left.H_{E}\right)$, and mean inbreeding levels $\left(F_{I S}\right)$. Significance of differences in these indices was tested using a two-sample $t$ test in R (R Core Team 2012).

\section{Regional population genetic diversity and structure}

The presence of isolation by distance was tested separately for native (Western Australia) and introduced populations (South Africa only) via Mantel tests using the online resource IBDWS v 3.16 (Jensen et al. 2005). Mantel tests were conducted using a matrix of pairwise genetic distances $\left(F_{S T}\right.$ values) against log-transformed geographical distances.

Genetic diversity indices - number of alleles $\left(N_{A}\right)$, number of private alleles $\left(N_{P A}\right)$, number of effective alleles $\left(N_{E}\right)$, unbiased expected heterozygosity $\left(u H_{E}\right), H_{O}$, and $F_{I S}$-were calculated per region (Western Australia and introduced regions by country) in GenAlEx v 6.5.02 (Peakall and Smouse 2012). Significance of differences in these indices between native and non-native (South Africa and South Australia only) populations was tested using a two-sample $t$ test in R (R Core Team 2012). Analysis of molecular variance (AMOVA) of microsatellite allele frequencies was done partitioning variance among native and introduced regions, among populations within regions, and within populations using ARLEQUIN (Excoffier and Lischer 2010) with 10,000 permutations.

Population genetic structure was inferred using a Bayesian clustering algorithm implemented in STRUCTURE v2.3.2 (Falush et al. 2007). A spatially explicit, admixed model was selected as it offers an improved method for identifying the optimal number of genetic clusters (François and Durand 2010). STRUCTURE HARVESTER (Earl and von Holdt 2011) and the $\Delta K$ method of Evanno et al. (2005) was used to determine the number of genetic clusters in all native and introduced populations. All models were run for 1,000.000 generations, of which 100,000 were discarded as burn-in. $K$ values were simulated from one upwards until $K$ exceeded the total number of collected populations. After determining the number of genetic clusters $(K)$ for the full dataset (referred to as level 1 analysis hereafter), each individual was assigned to the genetic cluster for which its inferred ancestry was the highest, provided this value was higher than 0.6 , i.e. more than $60 \%$ of the genome assigned to a particular cluster. This allowed us to hierarchically detect sublevels of genetic structure (Coulon et al. 2008) by repeating the analyses described above for each of the genetic clusters identified during level 1 analysis separately (referred to as level 2 analysis hereafter). To assess the strength of the clusters inferred by the level 2 STRUCTURE analysis, among-cluster $F_{S T}$ values were calculated using FreeNA (Chapuis and Estoup 2007). We also used the 'lattice' package in R (R Core Team 2012) to create a heat map of population pairwise, null allele-corrected $F_{S T}$ values estimated in FreeNA (Chapuis and Estoup 2007). The significance of inferred population genetic structure $\left(F_{S T}\right.$ values) among invasive populations, among invasive and native populations, and among native populations was assessed using permutation tests with 1000 iterations in GenAlEx v 6.5.02 (Peakall and Smouse 2012).

\section{DNA sequence variation and structure}

DNA sequencing data were employed to investigate the historical population genetic structure of $P$. lophantha. The nuclear external transcribed spacer (ETS) region was amplified for a subset of collected individuals (Table S1) using primers described in Brown et al. (2008) and the PCR setup and conditions described in Le Roux et al. (2011). Sequence data were visualised and edited in BIOEDIT version 7.0.5.3 (Hall 1999). We also included sequence data from GenBank representatives of $P$. lophantha subsp. lophantha (GenBank accession numbers EF638104, HM800431, HM800432) and from a previous study (Le Roux et al. 2011). The final dataset comprised 65 accessions.

To assess the distribution of genetic variation between native and introduced populations, an AMOVA was used in the ARLEQUIN software package (Excoffier and Lischer 2010) using 10,000 permutations and the same hierarchical setup as for the microsatellite data. To assess relationships between nuclear DNA sequences, we reconstructed haplotype networks using statistical parsimony with a $95 \%$ connection limit in TCS v.1.21 (Clement et al. 2000).

\section{Results}

Most populations had loci displaying significant departures from Hardy-Weinberg equilibrium. Native Western Australian populations harboured more alleles than those in the introduced range ( $N_{A}=3.90$ vs. 3.17$)$, had more private 
alleles $\left(N_{P A}=6\right.$ vs. 3.29), and more polymorphic loci $\left(P_{L}=8.29\right.$ vs. 7.35$)$. They also displayed lower levels of inbreeding $\left(F_{I S}=0.46\right.$ vs. 0.66$)$ and had higher levels of observed heterozygosity $\left(H_{O}=0.31\right.$ vs. 0.18 , Table $\left.S 3\right)$, although of all genetic diversity indices measured, only expected heterozygosity was significantly different between native and introduced populations $\left(H_{E}=0.58\right.$ in native vs. 0.51 in introduced Table S3).

\section{Regional population genetic diversity and structure}

There was no evidence of significant isolation by distance in either Western Australian $\left(R^{2}=0.009, P=0.296\right)$ or South African $\left(R^{2}=0.0144, P=0.220\right)$ ranges of $P$. lophantha subsp. lophantha (Fig. S2). Overall, native Western Australian populations were more diverse than introduced populations, displaying higher levels of alleles, private alleles, and effective alleles (Table 1). Observed heterozygosity was highest in Maui $\left(H_{O}=0.30\right)$ and lowest in Portugal $\left(H_{O}=0.05\right)$. Levels of inbreeding were high and similar for all regions sampled, indicating a deficit in heterozygosity (Table 1, Table S3). South Africa and Maui were the most genetically diverse introduced populations, displaying the highest levels of private and effective alleles compared to other introduced populations (Table 1).

Most microsatellite genetic diversity resided within populations $(66.11 \%)$ and the least among native and introduced ranges (variance $=4 \%$, Table 2). The AMOVA was supported by low but significant levels of differentiation between native and introduced ranges $\left(F_{S T}=0.08, P \leq 0.001\right.$; Fig. 2$)$. At the regional level, the lowest level of population differentiation was estimated among native Western Australian populations and introduced South African populations $\left(F_{S T}<0.01\right.$; Fig. 2). Within native Western Australia populations showed significant population genetic structure $\left(F_{S T}=0.16, P \leq 0.001\right)$.
Level 1 of the hierarchical Bayesian clustering analyses including all native and introduced populations identified two genetic clusters $(K=2)$ with relatively low differentiation $\left(F_{S T}=0.14\right.$, Fig. 1a), mostly corresponding to native and introduced populations. The level 2 STRUCTURE analysis identified six genetic clusters $(K=6$, Fig. 1b, c, Fig. S3) with low to moderate levels of differentiation (low $F_{S T}=0.112$ between blue and green clusters; moderate $F_{S T}=0.436$ between red and purple clusters, Fig. 1, Fig. S3). Among invasive populations, single genetic clusters with limited or no admixture were present in populations from Portugal (population POR), the Hawaiian Islands (HAW), South Africa (PIK and VAN), and the introduced range in Australia (CCP, MTJ, and ADE).

In the native Western Australian range, our clustering analysis indicated that all six genetic clusters identified in the level 2 analysis were present (Fig. 1b, c, Fig. S3). Single genetic clusters with limited or no admixture were evident for populations collected from Jarrahdale and Margaret River (populations JAR and MAR). The remainder of invasive and native populations showed some evidence of admixture between two or more genetic clusters (Fig. 1b, c).

\section{DNA sequence variation and phylogeographic structure}

As with the microsatellite data, levels of genetic diversity for nuclear ETS DNA sequencing data were lowest between the native and introduced ranges and highest within populations (Table 2). Network analysis retrieved ten unique DNA sequences and low intra-specific divergence within the 65 individuals of $P$. lophantha subsp. lophantha contained within a single network (Fig. 3). Two high-frequency sequences were shared between individuals collected in Western Australia, eastern Australia, and South Africa (Fig. 3). All sequences identified from native populations were also found in introduced

Table 1 Regional genetic diversity indices for native and introduced populations of Paraserianthes lophantha genotyped at 11 nuclear microsatellite loci

\begin{tabular}{|c|c|c|c|c|c|c|c|}
\hline Population & $N$ & $N_{A}$ & $N_{P A}$ & $N_{E}$ & $H_{O}$ & $u H_{E}$ & $F_{I S}$ \\
\hline \multicolumn{8}{|l|}{ Native } \\
\hline Western Australia & 70 & $12.82(2.03)$ & $5.73(1.57)$ & $5.92(1.13)$ & $0.16(0.04)$ & $0.72(0.07)$ & $0.80(0.04)$ \\
\hline \multicolumn{8}{|l|}{ Introduced } \\
\hline South Australia & 24 & $3.73(0.65)$ & $0.36(0.24)^{*}$ & $2.10(0.29)^{*}$ & $0.11(0.05)$ & $0.43(0.09)$ & $0.75(0.09)$ \\
\hline Hawaii $^{\mathrm{a}}$ & 20 & $6.09(0.88)$ & $3.10(0.74)$ & $3.13(0.66)$ & $0.30(0.08)$ & $0.60(0.05)$ & $0.55(0.09)$ \\
\hline Portugal $^{\mathrm{a}}$ & 10 & $1.45(0.43)$ & $0.10(0.09)$ & $1.11(0.33)$ & $0.05(0.02)$ & $0.21(0.09)$ & $0.68(0.14)$ \\
\hline South Africa & 114 & 8.64 (1.47) & $2.45(0.82)^{*}$ & $3.7(0.07)^{*}$ & $0.16(0.09)$ & $0.60(0.09)$ & $0.79(0.07)$ \\
\hline
\end{tabular}

Standard error of the mean values represented in parenthesis

$N$ number of individuals per group, $N_{A}$ mean number of alleles, $N_{P A}$ number of private alleles, $N_{E}$ number of effective alleles, $H_{O}$ mean observed heterozygosity, $u H_{E}$ unbiased expected heterozygosity, $F_{I S}$ mean inbreeding coefficient

*Significantly different from the native range

${ }^{a}$ Populations for which significance was untested due to low sample size 
Table 2 Hierarchical AMOVA partitioning genetic variation in Paraserianthes lophantha subspecies lophantha at three levels: among native and invasive ranges, among populations, and within populations within native and invasive ranges

\begin{tabular}{lllll}
\hline & $d . f$. & Sum of squares & Percent variation (\%) & $P$ value \\
\hline Microsatellite data & & & & \\
$\quad$ Among native and invasive range & 1 & 33.59 & 4.00 & $<0.001$ \\
Among populations & 22 & 280.88 & 29.89 & $<0.001$ \\
$\quad$ Within populations & 214 & 517.87 & 66.11 & $<0.050$ \\
Sequence data & & & & $<0.001$ \\
$\quad$ Among native and invasive range & 1 & 0.68 & 2.31 & $<0.001$ \\
Among populations & 14 & 6.98 & 42.15 & 0.094 \\
$\quad$ Within populations & 38 & 5.38 & 55.54 & \\
\hline
\end{tabular}

populations, but five sequences were uniquely present in introduced populations - two in Maui, one in Portugal, and two in South Africa.

\section{Discussion}

High genetic diversity in the introduced ranges of non-native species has been repeatedly linked with multiple introductions and, in some instances, their invasive success (e.g. Lavergne and Molofsky 2007; Rollins et al. 2009; Tang et al. 2009; Gaudeul et al. 2011). The amount of genetic diversity in the introduced range is dependent on the interplay between introduction history and the genetic structure present within the native range. We found substantial intra-specific genetic diversity that is geographically structured in the Western Australian native range of $P$. lophantha subsp. lophantha, i.e. similar genetic clusters are in close geographic proximity but are isolated from other such clusters. We also provide support that multiple individuals from a number of Western

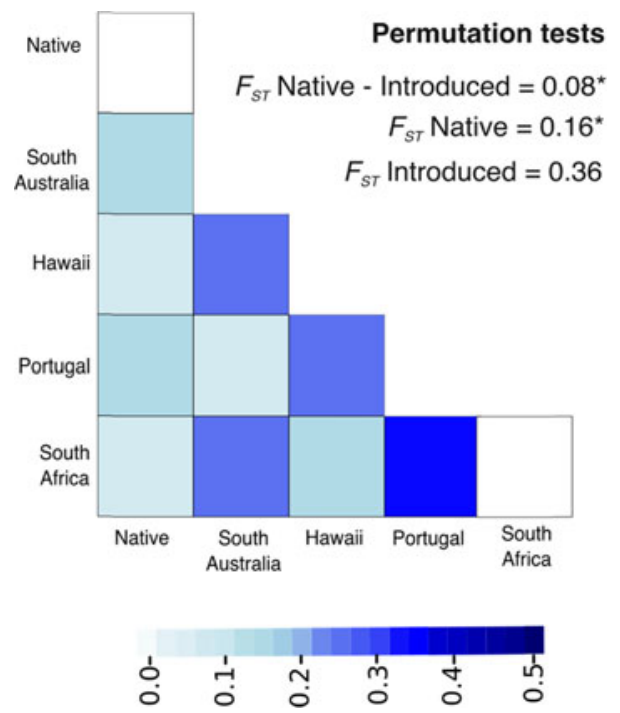

Fig. 2 Heat map of pairwise $F_{S T}$ values estimated between regional (introduced and native) populations of Paraserianthes lophantha subspecies lophantha. The significance of regional $F_{S T}$ values was evaluated using 1000 permutations (asterisks indicate $P \leq 0.001$ )
Australian genetic clusters have been introduced to South Africa, whereas introductions to Portugal and the Hawaiian Islands are of less diverse origins. This is congruent with other studies on closely related taxa-species native to Western Australia that have high genetic structure and that were introduced to South Africa on multiple occasions have diverse and admixed genotypes in South Africa (e.g. Acacia cyclops, Le Roux et al. 2011; A. saligna, Thompson et al. 2012).

$P$. lophantha subsp. lophantha was independently introduced in 1833 and 1835 to the Western Cape Province of South Africa. These introductions were directly from Australia and were likely characterised by low propagule pressure (number and size of introduction events, Stirton 1978). Therefore, based on our clustering analyses, these introductions must have included propagules sourced from several populations in Western Australia prior to their arrival in South Africa. High genetic diversity in the introduced range as a result of wide geographic sampling and/or widespread plantings within Australia has been previously reported for wattles imported to South Africa and elsewhere in the world (e.g. Acacia pycnantha, Le Roux et al. 2013; A. saligna, Thompson et al. 2015). Such genetic data corroborate the well-documented introduction histories for many Australian wattles which indicates that, in many instances, wide geographic sampling occurred in Australia prior to the dissemination of propagules in South Africa (e.g. A. mearnsii was introduced to South Africa from over 20 provenances throughout its native range; Poynton 2009).

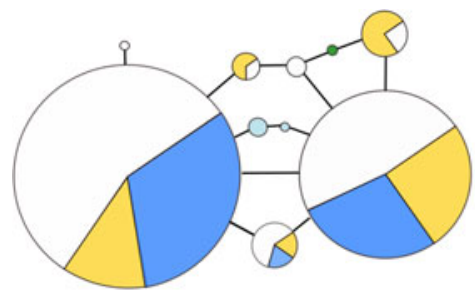

Native

$\square$ Western Australia

Introduced
$\square$ South Africa
$\square$ Hawaii
$\square$ South Australia, New South Wales \&
$\square$ Portugal

Fig. 3 Relationships among unique Paraserianthes lophantha nDNA (ETS, $n=65$ ) sequences based on statistical parsimony. Each circle represents a unique DNA sequence; circle sizes are proportional to ETS sequence frequencies. Colours indicate the relative proportion of ETS sequences in different regions, and connecting lines indicate single mutational steps between sequences 
We found no records of the introduction history of P. lophantha subsp. lophantha to eastern Australia, Portugal, and the Hawaiian Islands. However, Portuguese populations harboured extremely low levels of genetic diversity (allelic diversity, observed heterozygosity), suggesting an introduction event characterised by low propagule pressure, however, this may also be because we sampled a single population in Portugal. By contrast, the Maui population in the Hawaiian Islands, while representing a single genetic cluster based on Bayesian assignment tests and one population, harboured substantial genetic diversity and showed moderate levels of observed heterozygosity. This may indicate substantial propagule pressure, but with propagules sourced from a geographically restricted range in Western Australia (e.g. Margaret River area). All populations, irrespective of origin, consistently showed significant deficits in heterozygosity and, subsequently, high levels of inbreeding.

Although $P$. lophantha from the Hawaiian Islands is thought to be subspecies montana (Oppenheimer et al. 2002), and despite the unique ETS genotypes and many private microsatellite alleles identified within the Maui population, the differentiation observed here does not clearly separate Hawaiian accessions from Western Australian accessions. Various other studies have distinguished closely related subspecies of Acacia using the same genetic markers used in this study (e.g. A. pycnantha, Ndlovu et al. 2013; A. saligna, Thompson et al. 2012, 2015). In fact, population differentiation based on microsatellite data between Hawaiian and Western Australian populations was similar to the differentiation between South Africa and Western Australia (Fig. 2). The most parsimonious conclusion is that Hawaiian populations were incorrectly identified and are in fact $P$. lophantha subsp. lophantha. In their taxonomic treatment, Barneby and Grimes (1996) state "A species [P. lophantha] of bicentric range in East Indies and S W Australia of which the typical subspecies, endemic to S W Australia, has been cultivated in tropical and warm-temperate regions of both hemispheres...", further supporting the global movement of a single subspecies. Barneby and Grimes (1996) also proposed an alternative classification reducing $P$. lophantha to a single taxon (with no subspecies) that is morphologically variable but which displays low levels of genetic divergence. Unfortunately, a lack of data for the native range of $P$. lophantha subsp. montana precludes any inferences about the presence of subspecies montana outside its native range. To better understand the intra-specific genetic variation within $P$. lophantha, future work should include material from the native regions of subspecies montana in southern Indonesia.

Overall, our approach was able to identify contrasting genetic signatures in introduced populations of $P$. lophantha subsp. lophantha and reinforces the need to consider native intra-specific diversity and a species' history of introduction when attempting to reconstruct invasion histories.
Acknowledgments We acknowledge the financial support from the DST-NRF Centre of Excellence for Invasion Biology and the Working for Water Programme through the collaborative research project on 'Research for Integrated Management of Invasive Alien Species'. J. L. R. acknowledges the support from the Oppenheimer Memorial Trust (grant 19820/02) and the HB \& MJ Thom Award (Stellenbosch University) for sabbatical research funding. D. M. R. acknowledges the support from the National Research Foundation (grant 85417) and the Oppenheimer Memorial Trust. We thank collectors from around the world for providing plant material, in particular Gillian Brown (Australia), Elizabete Marchante and Hélia Marchante (Portugal), and Forest Starr and Kim Starr (Hawaii, USA).

Data Archiving Statement All DNA Sequence data are available on the GenBank online repository (accession numbers KU727902KU727943).

\section{References}

Alston KP, Richardson DM (2006) The roles of habitat features, disturbance, and distance from putative source populations in structuring alien plant invasions at the urban/wildland interface on the Cape Peninsula, South Africa. Biol Conserv 132:183-198. doi:10.1016/ j.biocon.2006.03.023

Barneby RC, Grimes JW (1996) Silk tree, guanacaste, monkey's earring : a generic system for the synandrous Mimosaceae of the Americas. Part 1. Abarema, Albizia, and allies. The New York Botanical Garden Press, New York

Barrett SCH, Husband BC (1990) In: Brown AHD, Clegg MT, Kahler AL, Weir BS (eds) Plant population genetics, breeding, and genetic resources. Sinauer Associates Inc., Sunderland, pp 254-277

Blackburn TM, Pyšek P, Bacher S, Carlton JT, Duncan RP, Jarošík V, Wilson JRU, Richardson DM (2011) A proposed unified framework for biological invasions. Trends Ecol Evol 26:333-339. doi:10. 1016/j.tree.2011.03.023

Brown GK, Gardner MG (2011) Isolation, characterisation and transferability of microsatellites for Paraserianthes lophantha, Cape Wattle (Leguminosae: Mimosoideae): a significant weed worldwide. Muelleria 29:87-92, http://www.rbg.vic.gov.au/documents/ Muelleria_29\%281\%29\%2C_Brown_Gardner.pdf

Brown GK, Murphy DJ, Miller JT, Pauline YL (2008) Acacia s.s. and its relationship among tropical legumes, tribe Ingeae (Leguminosae: Mimosoideae). Syst Bot 33:739-751. doi:10.1600/ 036364408786500136

Brown GK, Murphy DJ, Ladiges PY (2011) Relationships of the Australo-Malesian genus Paraserianthes (Mimosoideae: Leguminosae) identifies the sister group of Acacia sensu stricto and two biogeographical tracks. Cladistics 27:380-390. doi:10. 1111/j.1096-0031.2011.00349.x

Butcher PA, Decroocq S, Gray Y, Moran GF (2000) Development, inheritance and cross-species amplification of microsatellite markers from Acacia mangium. Theor Appl Genet 101:1282-1290. doi:10. $1007 / \mathrm{s} 001220051608$

Chapuis MP, Estoup A (2007) Microsatellite null alleles and estimation of population differentiation. Mol Biol Evol 24:621-631. doi:10.1093/ molbev/msl191

Clement M, Posada D, Crandall KA (2000) TCS: a computer program to estimate gene genealogies. Mol Ecol 9:1657-1659. doi:10.1046/j. 1365-294x.2000.01020.x

Coulon A, Fitzpatrick JW, Bowman R, Stith BM, Makarewich CA, Stenzler LM, Lovette IJ (2008) Congruent population structure inferred from dispersal behaviour and intensive genetic surveys of the 
threatened Florida scrub-jay (Aphelocoma coerulescens). Mol Ecol 17:1685-1701. doi:10.1111/j.1365-294X.2008.03705.x

Doyle J, Doyle J (1990) Isolation of plant DNA from fresh tissue. Focus 12:12-15

Earl DA, von Holdt BM (2011) STRUCTURE HARVESTER: a website and program for visualizing STRUCTURE output and implementing the Evanno method. Conserv Genet Resour 4:359 361. doi:10.1007/s12686-011-9548-7

Evanno G, Regnaut S, Goudet J (2005) Detecting the number of clusters of individuals using the software STRUCTURE: a simulation study. Mol Ecol 14:2611-2620. doi:10.1111/j.1365-294X.2005.02553.x

Excoffier L, Lischer HEL (2010) Arlequin suite ver 3.5: a new series of programs to perform population genetics analyses under Linux and Windows. Mol Ecol Resour 10:564-567. doi:10.1111/j.1755-0998. 2010.02847.x

Falush D, Stephens M, Pritchard JK (2007) Inference of population structure using multilocus genotype data: dominant markers and null alleles. Mol Ecol Notes 7:574-578. doi:10.1111/j.1471-8286.2007. 01758.x

François O, Durand E (2010) Spatially explicit Bayesian clustering models in population genetics. Mol Ecol Resour 10:773-784. doi: 10.1111/j.1755-0998.2010.02868.x

Gaertner M, Nottebrock H, Fourie H, Privett SDJ, Richardson DM (2012) Plant invasions, restoration, and economics: perspectives from South African fynbos. Perspect Plant Ecol Evol Syst 14:341-353. doi:10.1016/j.ppees.2012.05.001

Gaudeul M, Giraud T, Kiss L, Shykoff JA (2011) Nuclear and chloroplast microsatellites show multiple introductions in the worldwide invasion history of common ragweed, Ambrosia artemisiifolia. PLoS One 6:e17658. doi:10.1371/journal.pone.0017658

Goudet J (2001) FSTAT, a program to estimate and test gene diversities and fixation indices (version 2.9.3). Available from http://www.unil. ch/izea/softwares/fstat.html. Updated from Goudet (1995)

Hall TA (1999) BioEdit: a user-friendly biological sequence alignment editor and analysis program for Windows 95/98/NT. 41:95-98. doi: 10.1021/bk-1999-0734.ch008

Henderson L (2001) Alien weeds and invasive plants. A complete guide to weeds and invaders in South Africa. Plant Protection Research Institute, Pretoria

Impson FAC, Kleinjan CA, Hoffmann JH, Post JA, Wood AR (2011) Biological control of Australian Acacia species and Paraserianthes lophantha (Willd.) Nielsen (Mimosaceae) in South Africa. Afr Entomol 19:186-207. doi:10.4001/003.019.0210

Jensen JL, Bohonak AJ, Kelley ST (2005) Isolation by distance, web service. BMC Genet 6:13. doi:10.1186/1471-2156-6-13

Lavergne S, Molofsky J (2007) Increased genetic variation and evolutionary potential drive the success of an invasive grass. Proc Natl Acad Sci U S A 104:3883-3888. doi:10.1073/pnas.0607324104

Le Roux JJ, Brown GK, Byrne M, Ndlovu J, Richardson DM, Thompson GD, Wilson JRU (2011) Phylogeographic consequences of different introduction histories of invasive Australian Acacia species and Paraserianthes lophantha (Fabaceae) in South Africa. Divers Distrib 17:861-871. doi:10.1111/j.1472-4642.2011.00784.x

Le Roux JJ, Richardson DM, Wilson JRU, Ndlovu J (2013) Human usage in the native range may determine future genetic structure of an invasion: insights from Acacia pycnantha. BMC Ecol 1:37. doi: $10.1186 / 1472-6785-13-37$

Lee CE (2002) Evolutionary genetics of invasive species. Trends Ecol Evol 17:386-391. doi:10.1016/S0169-5347(02)02554-5

Lockwood JL, Cassey P, Blackburn T (2005) The role of propagule pressure in explaining species invasions. Trends Evol Evol 20:223-227. doi:10.1016/j.tree.2005.02.004

Millar MA, Byrne M (2007) Characterization of polymorphic microsatellite DNA markers for Acacia saligna (Labill.) HL Wendl. (Mimosaceae). Mol Ecol Notes 7:1372-1374. doi:10.1111/j.14718286.2007.01890.x
Miller JT, Murphy DJ, Brown GK, Richardson DM, Gonzalez-Orozco CE (2011) The evolution and phylogenetic placement of invasive Australian Acacia species. Divers Distrib 848-860. doi:10.1111/j. 1472-4642.2011.00780.x

Ndlovu J, Richardson DM, Wilson JRU, O’Leary M, Le Roux JJ (2013) Elucidating the native sources of an invasive tree species, Acacia pycnantha, reveals unexpected native range diversity and structure. Ann Bot 111:895-904. doi:10.1093/aob/mct057

$\mathrm{Ng} \mathrm{CH}$, Koh SC, Lee SL, Ng KKS, Mark A, Norwati M, Wickenswari R (2005) Isolation of 15 polymorphic microsatellite loci in Acacia hybrid (Acacia mangium $\times$ Acacia auriculiformis). Mol Ecol Notes 5:572-575. doi:10.1111/j.1471-8286.2005.00994.x

Nielsen IC (1992) Flora Malesiana Mimosaceae (LeguminosaeMimosoideae). Series I - Spermatophyta. Revision Mimosaceae. Leiden University, The Netherlands: Rijksherbarium/ Hortus Botanicus

Oppenheimer H, Bartlett L, Randal T (2002) New plant records from the main Hawaiian Islands. Bishop Mus Occas Pap 69:1-14, http://hbs. bishopmuseum.org/pubs-online/pdf/op115p7-17.pdf

Peakall R, Smouse PE (2012) GenAlEx 6.5: genetic analysis in Excel. Population genetic software for teaching and research - an update. Bioinformatics 28:2537-2539. doi:10.1093/bioinformatics/bts460

Poynton RJ (2009) Tree planting in Southern Africa, volume 3: other genera. Department of Agriculture, Forestry and Fisheries, Pretoria

R Core Team (2012) R: a language and environment for statistical computing. R Foundation for Statistical Computing, Vienna

Randall RP (2002) A global compendium of weeds. Shannon Books, Melbourne

Rejmánek M, Richardson DM (2013) Trees and shrubs as invasive alien species-2013 update of the global database. Divers Distrib 19: 1093-1094. doi:10.1111/ddi.12075

Richardson DM, Carruthers J, Hui C et al (2011) Human-mediated introductions of Australian acacias - a global experiment in biogeography. Divers Distrib 17:771-787. doi:10.1111/j.1472-4642.2011. 00824. $\mathrm{x}$

Richardson DM, Le Roux JJ, Wilson JRU (2015) Australian acacias as invasive species: lessons to be learnt from regions with long planting histories. South For 77:31-39. doi:10.2989/20702620.2014.999305

Rollins LA, Woolnough AP, Wilton AN, Sinclair R, Sherwin WB (2009) Invasive species can't cover their tracks: using microsatellites to assist management of starling (Sturnus vulgaris) populations in Western Australia. Mol Ecol 18:1560-1573. doi:10.1111/j.1365294X.2009.04132.X

Rousset F (2008) genepop'007: a complete reimplementation of the genepop software for Windows and Linux. Mol Ecol Resour 8: 103-106. doi:10.1111/j.1471-8286.2007.01931.x

Sakai AK, Allendorf FW, Holt JS et al (2001) The population biology of invasive species. Annu Rev Ecol Syst 32:305-332. doi:10.1146/ annurev.ecolsys.32.081501.114037

Scott LJ, Congdon BC, Playford J (1998) Molecular evidence that fireweed (Senecio madagascariensis, Asteraceae) is of South African origin. Plant Syst Evol 213:251-257. doi:10.1007/BF00985204

GBIF Secretariat: English Wikipedia - Species Pages, 2015-02-07. Accessed via http://www.gbif.org/species/113607680 on 2016-0110.

Stirton CH (1978) Plant invaders; beautiful, but dangerous. ABC Press, Cape Town

Sunnucks P (2000) Efficient genetic markers for population biology. Trends Ecol Evol 15:199-203. doi:10.1016/S0169-5347(00) 01825-5

Tang SQ, Wei F, Zeng LY, Li XK, Tang SC, Zhong Y, Geng Y-P (2009) Multiple introductions are responsible for the disjunct distributions of invasive Parthenium hysterophorus in China: evidence from nuclear and chloroplast DNA. Weed Res 49:373-380. doi:10.1111/j. 1365-3180.2009.00714.x 
Taylor DR, Keller SR (2007) Historical range expansion determines the phylogenetic diversity introduced during contemporary species invasion. Evolution 61:334-345. doi:10.1111/j.1558-5646.2007. 00037.x

Thompson GD, Robertson MP, Webber BL, Richardson DM, Le Roux JJ, Wilson JRU (2011) Predicting the subspecific identity of invasive species using distribution models: Acacia saligna as an example. Divers Distrib 17:1001-1014. doi:10.1111/j.1472-4642.2011. 00820.x

Thompson GD, Bellstedt DU, Byrne M, Millar MA, Richardson DM, Wilson JRU, Le Roux JJ (2012) Cultivation shapes genetic novelty in a globally important invader. Mol Ecol 21:3187-3199. doi:10. 1111/j.1365-294X.2012.05601.x

Thompson GD, Bellstedt DU, Richardson DM, Wilson JRU, Le Roux JJ (2015) A tree well travelled: global genetic structure of the invasive tree Acacia saligna. J Biogeogr 42:305-314. doi:10.1111/jbi.12436

Thuiller W, Richardson DM, Rouget M, Procheș S, Wilson JRU (2006) Interactions between environment, species traits, and human uses describe patterns of plant invasions. Ecology 87:1755-1769. doi: 10.1890/0012-9658(2006)87[1755:IBESTA]2.0.CO;2

Walsh NG, Entwisle TJ (1996) Flora of Victoria, Dicotyledons (Winteracaea to Myrtaceae) Vol 3. Inkata Press, Melbourne

Wardill TJ, Graham GC, Zalucki M, Palmer WA, Playford J, Scott KD (2005) The importance of species identity in the biocontrol process: identifying the subspecies of Acacia nilotica (Leguminosae: Mimosoideae) by genetic distance and the implications for biological control. J Biogeogr 32:2145-2159. doi:10.1111/j.1365-2699. 2005.01348.x

Wilson JRU, Gairifo C, Gibson MR, Arianoutsou M et al (2011) Risk assessment, eradication, and biological control: global efforts to limit Australian Acacia invasions. Divers Distrib 17:1030-1046. doi: 10.1111/j.1472-4642.2011.00815.x

Yelenik SG, Stock WD, Richardson DM (2004) Ecosystem level impacts of invasive Acacia saligna in the South African fynbos. Restor Ecol 12:44-51. doi:10.1111/j.1061-2971.2004.00289.x 